\title{
Regioselective transformation of 6/5-fused bicyclic isoxazolidines to second-generation cyclic aldonitrones
}

\author{
Basem A. Moosa and Shaikh A. Ali* \\ Chemistry Department, King Fahd University of Petroleum and Minerals, \\ Dhahran 31261, Saudi Arabia \\ E-mail: shaikh@kfupm.edu.sa
}

\begin{abstract}
The cycloaddition reactions of 4-(2-hydroxy-2-propyl)-3,4,5,6-tetrahydropyridine 1-oxide with mono- and di-substituted alkenes have been found to be highly stereo- as well as face-selective. In solution, the 6/5 fused bicyclic cycloadducts remain solely as the cis-fused invertomers in order to accommodate the bulky tertiary substituent 2-hydroxy-2-propyl in the equatorial orientation. The cycloadducts, upon peracid oxidation, leads to the exclusive formation of synthetically important second-generation cyclic aldonitrones. The stereo- and face-selectivity of the cycloaddition reactions of these second-generation nitrones bearing substituents at $\mathrm{C}(4)$ and $\mathrm{C}(6)$ have been briefly examined. One interesting finding was that treatment of the first generation nitrone i.e., 4-(2-hydroxy-2-propyl)-3,4,5,6-tetrahydropyridine 1-oxide, with mercury(II) oxide afforded a novel bicyclic nitrone, 1-oxa-5,6-dehydro-6-azabicyclo[3,2,1]heptane 6-oxide.
\end{abstract}

Keywords: Cyclic nitrones, nitrone cycloaddition, stereoselectivity, face selectivity, peracid oxidation, conformational analysis

\section{Introduction}

The efficacy of 1,3-dipolar cycloaddition reaction of cyclic nitrones lies on the remarkable selectivity in the incorporation of multiple stereocenters in a single step. ${ }^{1-3}$ The pyrrolidine- and piperidine-based alkaloids, which are widespread in nature, can be accessed through the cycloaddition reaction of the parent five- 1 and six-membered cyclic nitrones, ${ }^{4}$ or the secondgeneration aldonitrones 3 and 5, respectively (Scheme 1). ${ }^{5}$ The five-membered aldonitrones 3 can be accessed regiospecifically by peracid-induced ring opening of the bicyclic isoxzolidines 2 (nitrone 1 alkene cycloaddition products). It has been suggested that the orientation of the nitrogen lone pair in 2 dictates the formation of the $\mathrm{N}$-oxide intermediate on the $\beta$-face of the nitrone; the subsequent ring opening leads the $\mathrm{C}(2)-\mathrm{O}^{-}$to abstract the nearby $\mathrm{H}_{\mathrm{b}}$ immediately, thereby 
leading to the exclusive formation of the aldonitrones 3 . $^{6}$ However, the proper utilization of the second-generation six-membered aldonitrones $\mathbf{5}$ has been severely hampered by the lack of selectivity $^{7}$ for the oxidation process in 6/5-fused isoxazolidines $\mathbf{4 a , b}\left(\mathrm{R}^{1}=\mathrm{H}\right.$ ) (Table in Scheme 1), where the synthetically less important ketonitrones $\mathbf{6 a , b}$ are obtained as the major products.
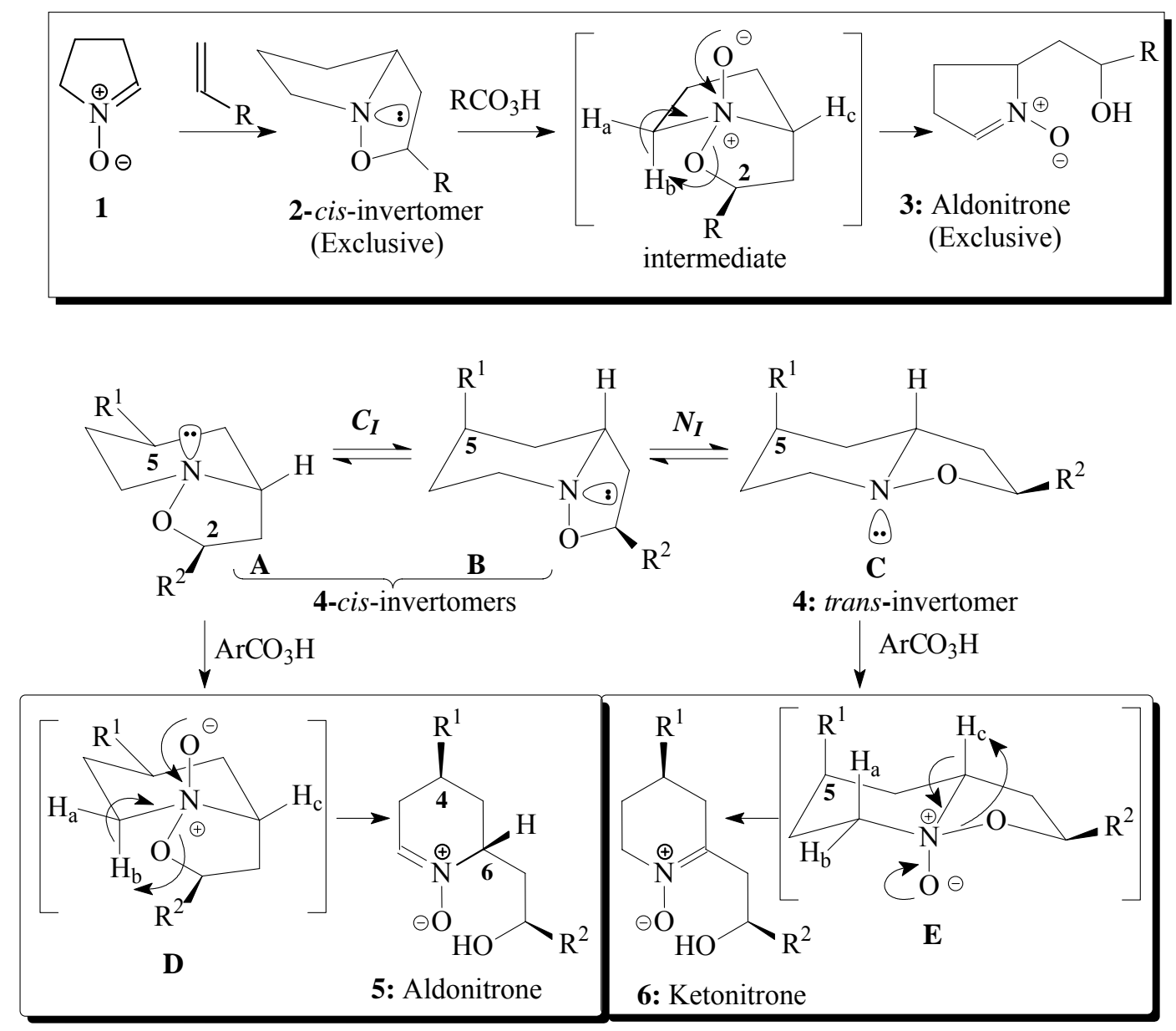

\begin{tabular}{ll|c|c}
\hline \multicolumn{1}{c|}{4} & $\begin{array}{c}\text { \% Composition of } \\
\text { invertomers } \\
\text { (cis/trans) }\end{array}$ & $\begin{array}{c}\text { \% Composition of } \\
\text { nitrones } \\
\text { (aldo-5/keto-6) }\end{array}$ \\
\hline a, $\mathrm{R}^{1}=\mathrm{R}^{2}=\mathrm{H}$ & $24: 76$ & $23: 77$ \\
b, $\mathrm{R}^{1}=\mathrm{H} ;$ & $\mathrm{R}^{2}=\mathrm{Ph}$ & $22: 78$ & $35: 65$ \\
c, $\mathrm{R}^{1}=\mathrm{CO}_{2} \mathrm{Bu} ;$ & $\mathrm{R}^{2}=\mathrm{Ph}$ & $55: 45$ & $52: 48$ \\
d, $\mathrm{R}^{1}=\mathrm{CH}_{2} \mathrm{OAc} ; \mathrm{R}^{2}=\mathrm{Ph}$ & $88: 12$ & $82: 18$ \\
\hline
\end{tabular}

\section{Scheme 1}


While the geometric compulsion makes sure that the 5/5-ring system in 2 remains cis-fused, its corresponding 6/5 ring system in cycloadducts 4 exists in three different conformations/configurations: the cis pair $\mathbf{A}$ and $\mathbf{B}$, in rapid equilibrium by chair inversion $\left(\mathbf{C}_{\mathbf{I}}\right)$, and its trans invertomer $\mathbf{C}$, in a relatively slow equilibrium with cis invertomer $\mathbf{B}$ by nitrogen inversion process $\left(\mathbf{N}_{\mathbf{I}}\right)$. It has been suggested that the higher activation barrier to nitrogen inversion $\left(\Delta \mathrm{G}^{\#}, \sim 70 \mathrm{~kJ} / \mathrm{mol}\right)^{7 \mathrm{~b}}$ than the oxidation process does not permit the Curtin-Hammett principle $^{8}$ to apply; as such the invertomer ratio reflects the ratio of the products keto- and aldonitrones. While the cis invertomer leads to aldonitrones 5 via intermediate $\mathbf{D}$, the trans invertomer affords the synthetically less important ketonitrones 6 via E. As evident from the Table included in the Scheme 1, the cycloadduct $\mathbf{4 a}$ having a cis/trans invertomer ratio of 24:76 afforded the alod-5/keto-6 nitrones in an almost identical ratio of 23:77. ${ }^{9}$ Likewise, $\mathbf{4 b}$ having a cis/trans invertomer ratio of 22:78 affords the aldo-5/keto-6 nitrones in a similar ratio of 35:65. ${ }^{7 \mathrm{~b}}$

Note that the placement of a substituent $\mathrm{R}^{1}$ at $\mathrm{C}(5)$ in cycloadducts 4 would favour the cis invertomer $\mathbf{A}$ at the expense of $\mathbf{B}$ and the trans invertomer $\mathbf{C}$, both of which places the $\mathrm{C}(5) \mathrm{R}^{1}$ in the unfavourable axial orientation. Exploring this idea, greater percentages of the aldonitrones 5

are obtained from peracid-induced oxidation of the isoxazolidines $\mathbf{4 c}$ and $\mathbf{4 d}{ }^{10,11}$ In our continuing endeavor to obtain the aldonitrones 5 regiospecifically, we intended to place at $\mathrm{C}(5)$ in $\mathbf{4}$ a very bulky substituent that would ascertain the exclusive presence of the invertomer $\mathbf{A}$ and exclude the $\mathrm{C}(5)$ axially-oriented $\mathrm{R}^{1}$ in cis $\mathbf{B}$ and trans invertomer $\mathbf{C}$. The current work describes our attempt to test the above proposition and confirm the mechanism of the peracid oxidation process.

\section{Results and Discussion}

The synthesis of nitrone 12, having a bulky $\mathrm{CMe}_{2} \mathrm{OH}$ at $\mathrm{C}(4)$ is outlined in Scheme 2. Amine 10 upon hydrogen peroxide oxidation in the presence of sodium tungstate ${ }^{12}$ in water afforded a mixture of nitrone 12 and hydroxylamine 11 which upon treatment with $\mathrm{NaBH}_{4}$ afforded the hydroxylamine 11 in pure form. The required nitrone 12 was then prepared by mercury(II) oxide oxidation of $\mathbf{1 1 .}$

Next, we pursued the addition reaction of nitrone 12 with various alkenes. The addition of monosubstituted alkene styrene 13a was found to be stereo-, as well as face-selective; a single adduct 14a was obtained in $80 \%$ yield. The ${ }^{1} \mathrm{H}$ NMR analysis of the crude as well as purified product failed to reveal the presence of any minor isomer. Likewise, the addition reaction of 1hexene $\mathbf{1 3 b}$ also afforded a single isomer 14b. The configuration of the adduct 14a and 14b was based on the sterically favourable exo approach (Scheme 2) of the $\mathrm{Ph}$ and $\mathrm{Bu}$ groups from the less hindered face (i.e. $\alpha$ face) of the nitrone. ${ }^{11}$ Such a high selectivity is surprising since the $\mathrm{C}(4)-\mathrm{CMe}_{2} \mathrm{OH}$ group, imparting the facial difference, is positioned at the furthest point from the nitrone functionality in 12, yet a surprisingly high selectivity in the addition reactions were observed. 
The addition of disubstituted alkenes methyl methacrylate 15 to the nitrone 12 also demonstrated a very high face- and stereoselectivity (Scheme 2); a nonseparable mixture of adducts $\mathbf{1 6}$ and $\mathbf{1 7}$ in a respective ratio of 95:5 was obtained. The major adduct $\mathbf{1 6}$ was obtained via $\alpha$-exo $(\mathrm{Me})$ approach. The stereochemistry is based on the precedent lietrature ${ }^{2 \mathrm{a}}-$ the parent nitrone 3,4,5,6-tetrahydropyridine 1-oxide is known to give major and minor adducts in a ratio of 96:4 as a result of a favourable secondary orbital interaction via an endo-oriented methoxycarbonyl group in the transition state.<smiles>CC(=O)C1CCNCC1C(C)(C)C1CCN(Cc2ccccc2)CC1</smiles>

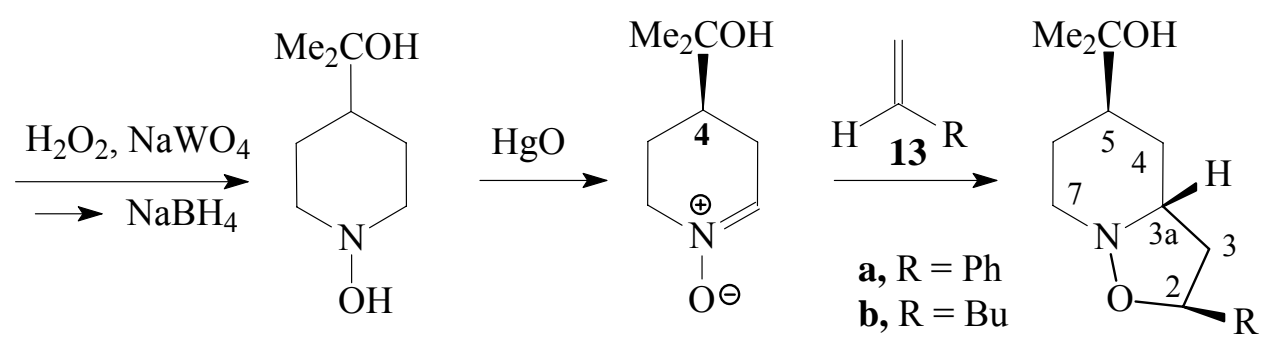

$11 \quad$ (Racemic) 12

14

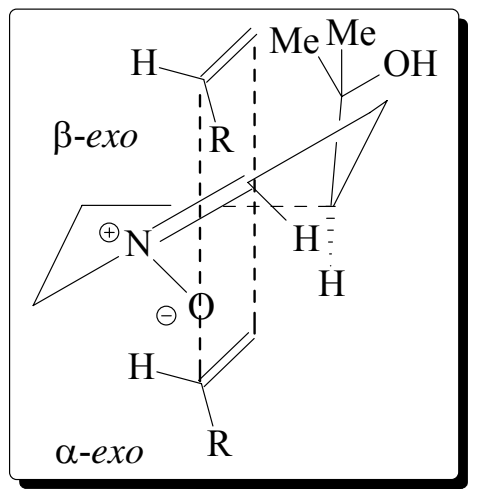

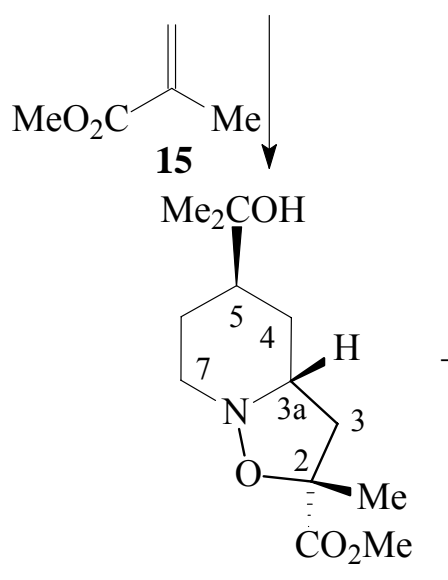

16

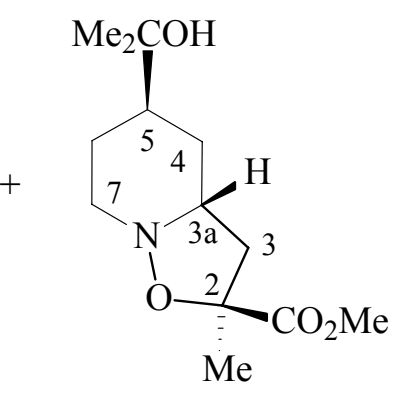

17

Scheme 2 
Since the stereochemistry of the ring fusion dictates the regiochemical outcome of the peracid oxidation process leading to the second-generation nitrones (vide supra) (Scheme 1), we have examined the conformational aspects as well as composition of the nitrogen invertomers (if any) by NMR spectroscopy. The presence of $-\mathrm{N}-\mathrm{O}-$ moiety in an organic molecule has a distinctive place in conformational analysis; ${ }^{13-15}$ oxygen being next to nitrogen raises the barrier to nitrogen inversion to such an extent that the individual invertomers can be identified by NMR spectroscopy. ${ }^{16}$ At ambient temperature, the ${ }^{1} \mathrm{H}$ and ${ }^{13} \mathrm{C}$ NMR spectra of these cycloadducts show sharp signals indicating the presence of a single invertomer for each of the compounds 14a, 14b and 16 as well as their corresponding acetate derivatives 18-20 obtained by reacting the former compounds with acetic anhydride in the presence of 4 -( $N, N$-dimethylamino)pyridine (DMAP) (Scheme 3).

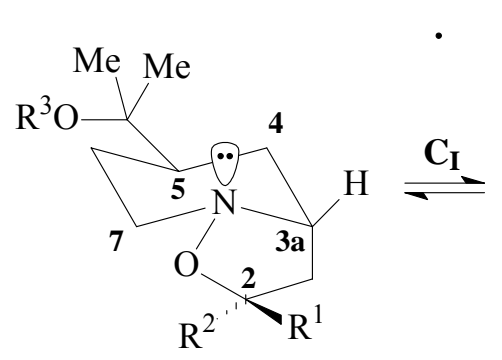

A (cis-fused)

Exclusive

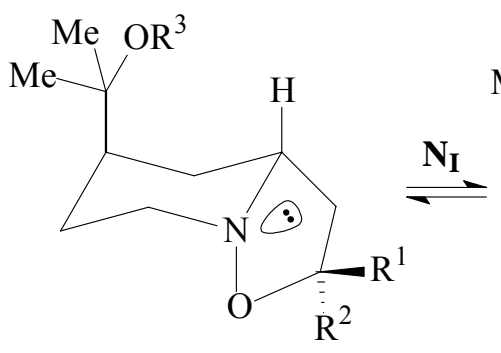

B (cis-fused)

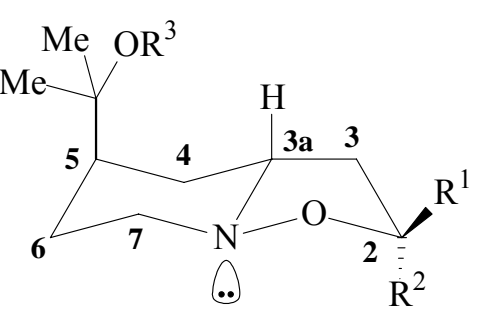

C (trans-fused)

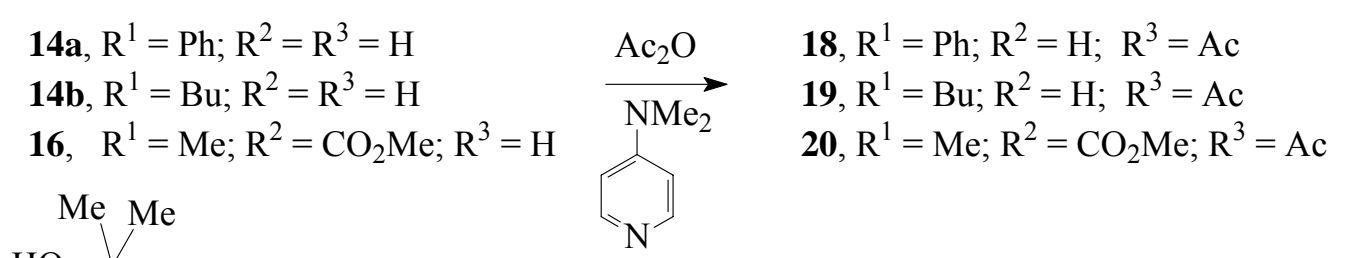

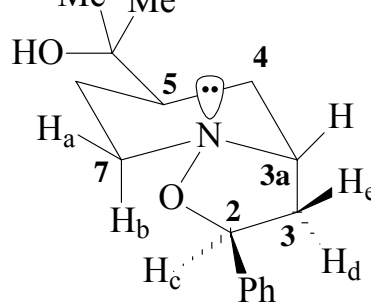

A (cis-fused)

Exclusive

14a
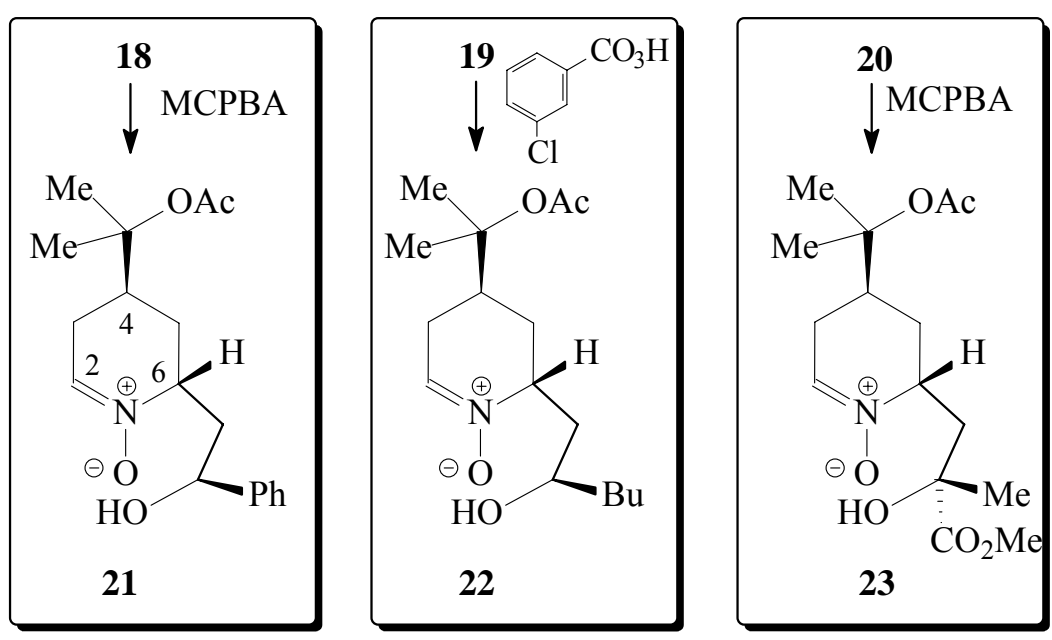

\section{Scheme 3}


With respect to the six-membered ring, both cis-fused $\mathbf{B}$ and trans-fused $\mathbf{C}$ have the bulky $\mathrm{CMe}_{2} \mathrm{OH}(\mathrm{Ac})$ substituent axially-oriented, while the tertiary group is equatorially oriented in cisfused A (Scheme 3). As such the major cycloadducts 14a, 14b and 16a, as well as their acetates 18-20, are expected to remain exclusively in the invertomeric form of cis-fused A. Note that for compound $\mathbf{4 a}$, the parent $6 / 5$ fused bicyclic isoxazolidine, a cis/trans ratio of 24:76 translates into a $\Delta \mathrm{G}^{\mathrm{o}}$ value (determined at $-50{ }^{\circ} \mathrm{C}$ ) of $2.11 \mathrm{~kJ} \mathrm{~mol}^{-1}$ favoring the $4 \mathrm{a}$-trans-fused invertomer, while for a cis/trans ratio of $22: 78$ for cycloadduct $\mathbf{4 b}, \Delta \mathrm{G}^{\mathrm{o}}$ value (determined at $+25{ }^{\circ} \mathrm{C}$ ) becomes $3.13 \mathrm{~kJ} \mathrm{~mol}^{-1}$ (Scheme 1). ${ }^{\mathrm{t}}$ Butyl group is well known to have a conformational enthalpy $\left(\Delta \mathrm{H}^{\mathrm{o}}\right)$ difference of $21 \mathrm{~kJ} \mathrm{~mol}^{-1}$. Comparing cis-fused $\mathbf{A}$ of 14a with its trans-fused $\mathbf{C}$, the bulky tertiary substituent $\mathrm{CMe}_{2} \mathrm{OH}$ (akin to a butyl group) at $\mathrm{C}(5)$ is expected to destabilize the latter invertomer by an approximate $\Delta \mathrm{H}^{\mathrm{o}}$ of $21 \mathrm{~kJ} \mathrm{~mol}^{-1}$, thereby implying an overall free energy $\left(\Delta \mathrm{G}^{\mathrm{o}}\right.$ ) advantage of about $18 \mathrm{~kJ} \mathrm{~mol}^{-1}$ (i.e. 21-3.13) for the cis-invertomer. (Note that the entropy difference $\left(\Delta S^{0}\right)$ between the two invertomeric forms is assumed to be zero since both the invertomers remain as $d l$-pairs and have no axis of rotation). Such an astronomical energy difference would predict the complete absence of the trans invertomer as far as NMR detection limit is concerned. That the stable invertomers have the configuration of cis-fused $\mathbf{A}$ as depicted in Scheme 3 get further credence from ${ }^{1} \mathrm{H}$ NMR spectroscopy. While the $\mathrm{C}(3 \mathrm{a}) \mathrm{H}$ is equatorially oriented in cis-fused $\mathbf{A}$, it is axially oriented in trans-fused $\mathbf{C}$. The equatorially and axially oriented protons are known ${ }^{11}$ to appear at the chemical shift values of $\delta 3.8$ and 3.3 ppm, respectively; the observed chemical shifts of $\sim \delta 3.8$ for the current compounds thereby ascertain the equatorial orientation of the $\mathrm{C}(3 \mathrm{a}) \mathrm{H}$ in the exclusive invertomer cis-fused A. Further credence to the conformational assignments came from NOESY experiment. Based on COSY correlation, the signals of $\mathrm{H}_{\mathrm{a}}, \mathrm{H}_{\mathrm{b}}, \mathrm{H}_{\mathrm{c}}, \mathrm{H}_{\mathrm{d}}$ and $\mathrm{H}_{\mathrm{e}}$ of 14a (Scheme 3) were found to appear at $\delta 3.25,2.83,5.40,2.75,2.03 \mathrm{ppm}$, respectively. A strong NOE peak was observed between the protons $\mathrm{H}_{\mathrm{b}}$ and $\mathrm{H}_{\mathrm{c}}$ as a result of their proximity, possible only in the conformer $\mathbf{A}$.

Assertion of the cis fusion of the ring juncture predicts that the synthesis of the desired second-generation aldonitrones regiospecifically may be achieved by the peracid oxidation process mentioned earlier. To our relief and delight, the isoxazolidines 18-20, on treatment with $m$-chloroperbenzoic acid (MCPBA) gave the aldonitrones 21-23 exclusively and in almost quantitative yields (Scheme 3). This is the first time a series of 6/5-fused isoxazolidines have been shown to generate the synthetically important aldonitrones regiospecifically.

The peracid oxidation was also carried out in protic solvent ethanol in the hope that it will be able to intercept the intermediate $\mathbf{B}$ to obtain its protonated species $\mathbf{C}$ which would then generate both the aldo- and ketonitrones by general base catalysed abstraction of the proton $\mathrm{H}_{\mathrm{a}}$ or $\mathrm{H}_{\mathrm{b}}$ and $\mathrm{H}_{c}$, respectively (Scheme 4). The oxidation of 20 with MCPBA in methanol did indeed generate two nitrones 23 and 24 in a respective ratio of 80:20. While the general base catalyzed proton abstraction would favour the formation of more substituted ketonitrone 24, its formation as a minor isomer certifies a certain degree of concertedness as depicted in intermediate $\mathbf{A}$ as well as a competitive abstraction of proton $\mathrm{H}_{\mathrm{b}}$ by $\mathrm{RO}^{-}$in $\mathbf{B}$ versus the protonation leading to $\mathbf{C}$. The nitrones are readily identified by the ${ }^{1} \mathrm{H}$ NMR spectral analysis. The nonoverlapping $\mathrm{H}_{\mathrm{c}}, \mathrm{H}_{\mathrm{d}}$ and 
$\mathrm{H}_{\mathrm{f}}$ of aldonitrone 23 appeared at $\delta 4.21,2.64(1 \mathrm{H}, \mathrm{dd}, \mathrm{J} 10.2,14.3 \mathrm{~Hz})$, and 7.08, respectively, while for the ketonitrone 24, the $\mathrm{Hg}$ and $\mathrm{H}_{\mathrm{h}}$ was displayed at $\delta 3.90$, and $\mathrm{H}_{\mathrm{i}}$ and $\mathrm{H}_{\mathrm{j}}$ at $3.23(\mathrm{~d}, J$ $13.6 \mathrm{~Hz}$ ) and $2.74(\mathrm{~d}, J 13.6 \mathrm{~Hz}) \mathrm{ppm}$.

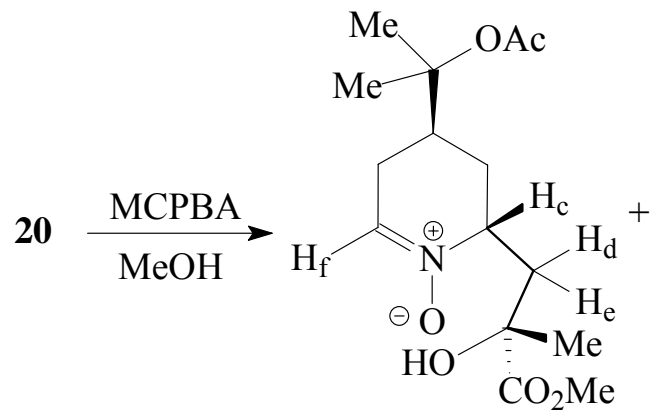

23

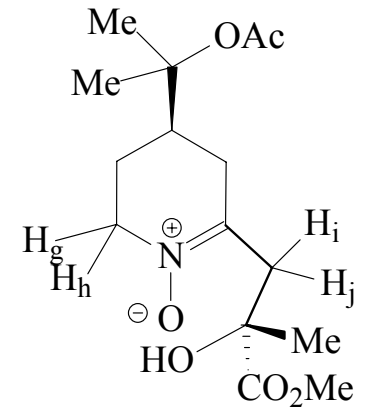

24

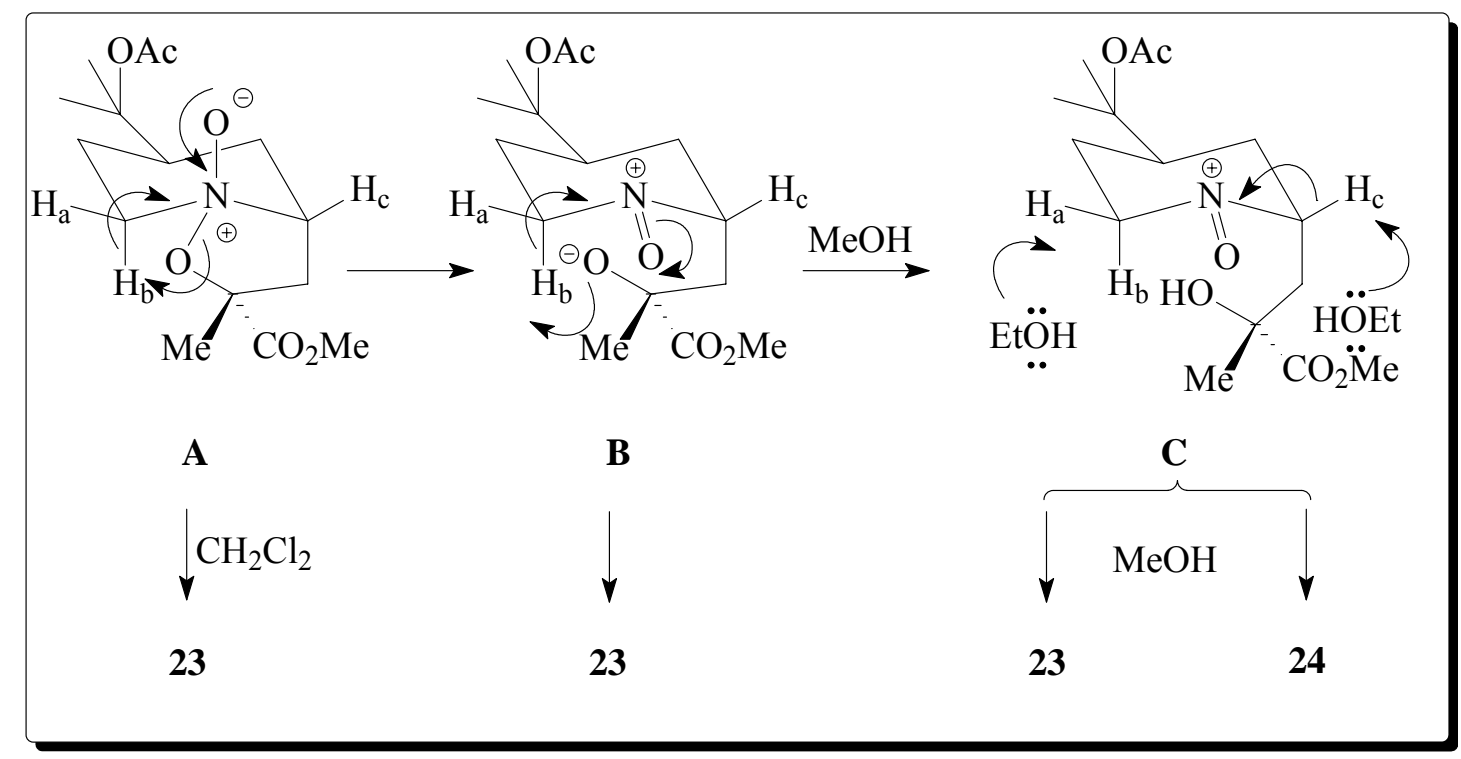

\section{Scheme 4}

Next, we explored the cycloaddition reaction of the second-generation nitrone 21 with the alkene 13; a nonseparable mixture of three adducts in a respective ratio of 89:8: 1) was obtained in $91 \%$ yield (Scheme 5). The addition was thus found to be highly face selective. The stereochemistry of the major adduct was based on the approach of the alkene from the $\beta$-face of the nitrone to give $\mathrm{C}(3 \mathrm{a}), \mathrm{C}(7)$-trans substituted adduct 25; in the $\alpha$-face approach, the $\mathrm{CO}_{2} \mathrm{Me}$ group is expected to experience severe steric crowding in the transition state. The face selectivity is thus dictated by the steric influence of the substituent at $C(6)$ so as to force the alkene to approach from the $\beta$-face of the nitrone whereby the smaller Hs at the unsubstituted end of the alkene are in a better position to negotiate with the steric encumbrance of $\mathrm{C}(4)$ substituent. The adduct 25 is expected to be equilibrating between the two invertomers in both of which the bulky 
tertiary substituent is placed at equatorial orientation. The ${ }^{1} \mathrm{H}$ as well as ${ }^{13} \mathrm{C}$ NMR spectra at ambient temperatures did indeed reveal broad signals.

For the addition reaction of styrene 13a with nitrone 21, a mixture of isomers $\mathbf{2 6}$ and $\mathbf{2 7}$ was obtained in a respective ratio of 1:3; the face selectivity is thus dictated by the steric influence of the $\beta$-substituent at $\mathrm{C}(4)$ so as to force the alkene to a preferable approach from the $\alpha$-face of the nitrone. The endo-oriented $\mathrm{H}$ of styrene will have very little discomfort in compare to the endooriented carbomethoxy as far as the steric encumbrance of the $\alpha$-oriented substituent at $C(6)$ is concerned. The stereochemical analyses thus revealed that the mono- 13a and disubstituted 15 alkenes prefer to approach the $\alpha$ - and $\beta$-face of the nitrone, respectively, and the experimental findings are rationalized in terms of the transition state structures depicted in Scheme 5.
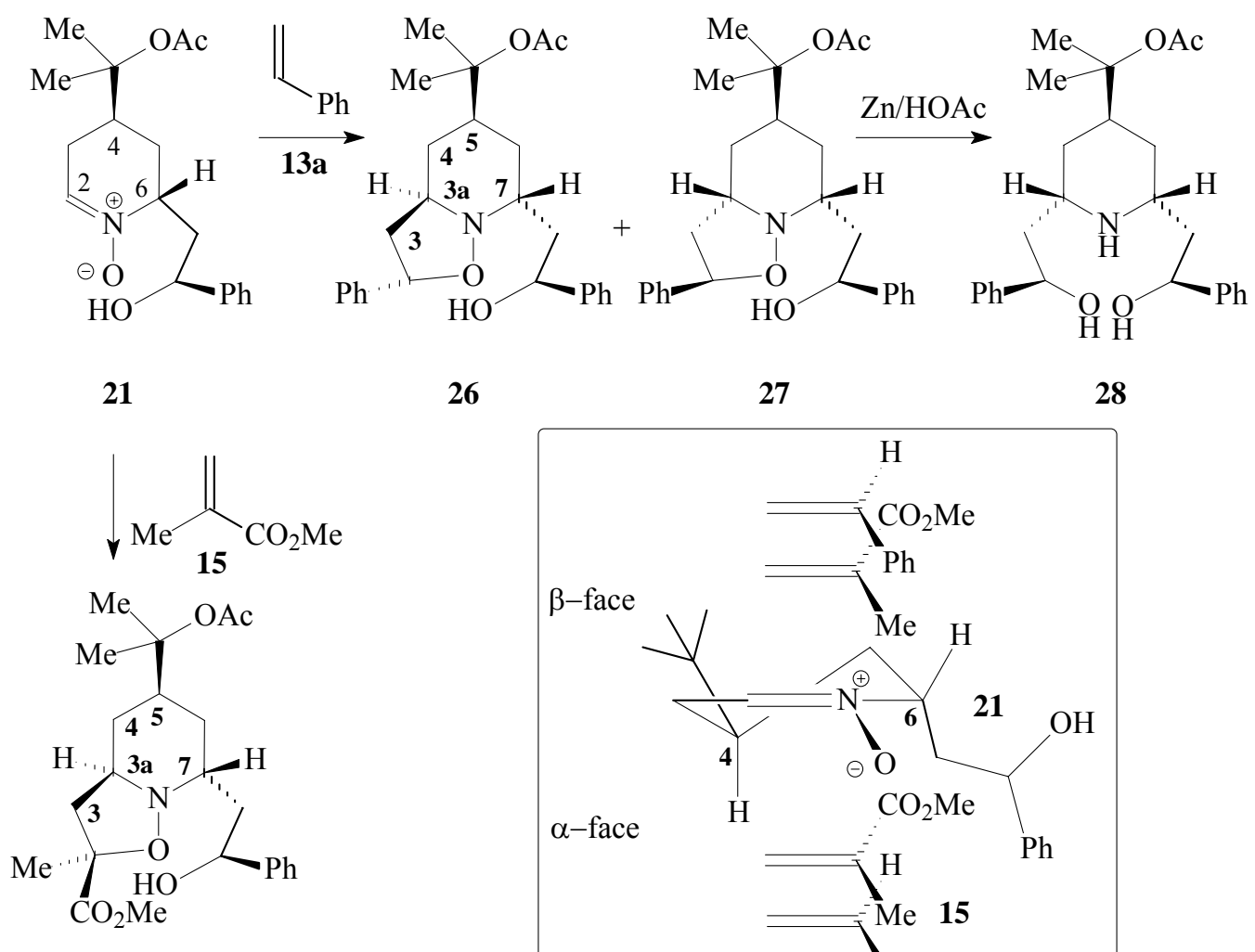

26

27

28

25
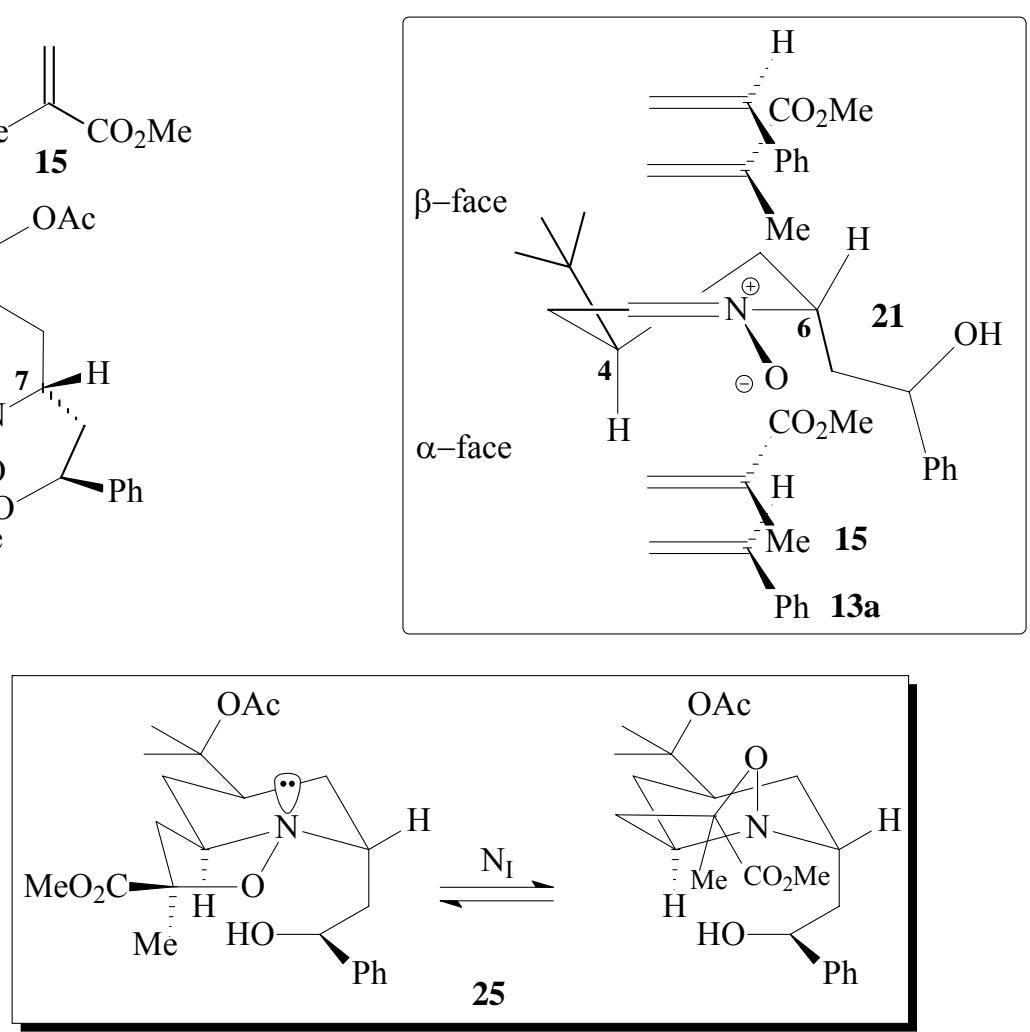

\section{Scheme 5}


The stereochemistry of the addition reaction was confirmed by chemical conversion of 27 into the ring opened product $\mathbf{2 8}$ by cleaving the $\mathrm{N}-\mathrm{O}$ bond of the cycloadducts with zinc/acetic acid. The NMR spectra of the amine $28\left(\mathrm{C}_{26} \mathrm{H}_{35} \mathrm{NO}_{4}\right)$, obtained from adduct 27 , confirmed its symmetric nature; as expected the ${ }^{13} \mathrm{C}$ NMR spectrum revealed the presence of 13 carbon signals. The two benzylic protons appeared identical as displayed by a single signal at $84.96-4.94$ $(2 \mathrm{H}, \mathrm{m})$; even the two phenyl rings appeared identical as displayed by three types of proton at $\delta 7.14(4 \mathrm{H}, \mathrm{d}, J 7.3 \mathrm{~Hz}), 7.24(4 \mathrm{H}, \mathrm{t}, J 7.3 \mathrm{~Hz}), 7.14(2 \mathrm{H}, \mathrm{t}, J 7.3 \mathrm{~Hz})$.

The very idea of having a 4-hydroxymethyl substituent in the current cyclic nitrone was our desire to synthesize a nitrone with an unusual bicyclic system as shown in Scheme 6. To our surprise, while the mercury(II) oxide oxidation of $\mathbf{1 1}$ in protic solvent ethanol afforded cleanly the monocyclic nitrone 12, the oxidation in aprotic solvent chloroform gave the novel bicyclic nitrone $\mathbf{2 9}$ in almost quantitative yield. The polar functionality of nitrone $\mathbf{1 2}$ is strongly solvated in ethanol; as a result, the internal aminalization of the nitrone moiety to the $N$-hydroxy compound $\mathbf{3 0}$ is discouraged. In an aprotic solvent, further oxidation of the intermediate $\mathbf{3 0}$ led to the bicyclic nitrone 29. Work is in progress on the cycloaddition reactions of this type of nitrone(s) with the aim of constructing and elaborating the unusal bicyclic system found in a novel inhibitor of tyrosyl tRNA synthetase. ${ }^{17}$

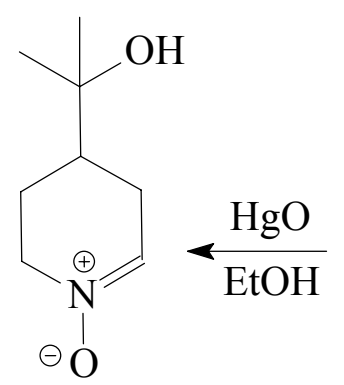

12

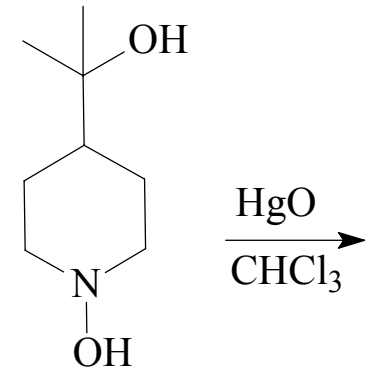

11

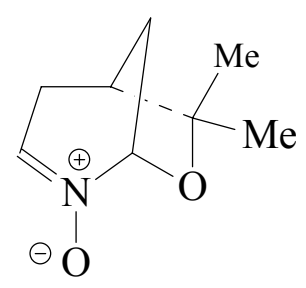

29

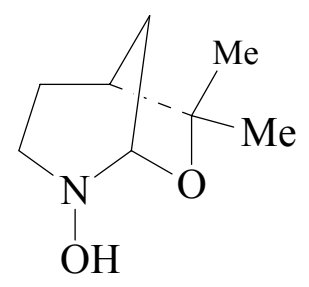

30

\section{Scheme 6}

The study has confirmed the mechanism of the peracid induced ring opening of the isoxazolidine, and led to the synthetically important second-generation cyclic aldonitrones, for the first time, with a complete regioselectivity. The bulkier tertiary substituent at $\mathrm{C}(5)$ in the 
cycloadducts has, to our advantage, frozen the invertomer exclusively in the cis-fused form and thus led to the observed regioselectivity. The synthesis of the novel bicyclic nitrone $\mathbf{2 9}$ has paved the way to study its cycloaddition reactions to incorporate and elaborate this interesting and unusal bicyclic system.

\section{Experimental Section}

General. Elemental analysis was carried out on a Perkin Elmer Elemental Analyzer Series 11 Model 2400. IR spectra were recorded on a Perkin Elmer 16F PC FTI.R spectrometer. ${ }^{1} \mathrm{H}$ and ${ }^{13} \mathrm{C}$ NMR spectra were measured in $\mathrm{CDCl}_{3}$ at $+25^{\circ} \mathrm{C}$ using TMS as internal standard on a JEOL LA $500 \mathrm{MHz}$ spectrometer. Mass spectra were recorded on a GC/MS system (Agilent Technologies, 6890N). Silica gel chromatographic separations were performed with Silica gel 100 from Fluka Chemie AG (Buchs, Switzerland). 4-methoxycarbonylpiperidine 7, 1-hexene, styrene, methyl methacrylate, m-chloroperbenzoic acid, from Fluka Chemie AG (Buchs, Switzerland) were used as received. All solvents were of reagent grade. Dichloromethane was passed through alumina before use. All reactions were carried out under $\mathrm{N}_{2}$.

N-Benzyl-4-methoxycarbonylpiperidine (8). To a stirring solution of amine 7 (10 g, $70 \mathrm{mmol})$ in THF $(50 \mathrm{~mL})$ in the presence of triethyl amine $(7 \mathrm{~g})$ at $0^{\circ} \mathrm{C}$ was added benzyl bromide $(13.2 \mathrm{~g}$, $70 \mathrm{mmol}$ ) dropwise. After stirring at room temperature overnight, the mixture was taken up in water $(20 \mathrm{~mL})$ and extracted with $\mathrm{CH}_{2} \mathrm{Cl}_{2}(4 \times 30 \mathrm{~mL})$. The combined organic layers was dried $\left(\mathrm{Na}_{2} \mathrm{SO}_{4}\right)$, concentrated and the residual liquid was distilled to give amine 8 as a colorless liquid (15.3 g, 94\%), bp 0.1 mbarHg $104{ }^{\circ} \mathrm{C}$; (Found: $\mathrm{C}, 71.9 ; \mathrm{H}, 8.2 ; \mathrm{N}, 5.8 . \mathrm{C}_{14} \mathrm{H}_{19} \mathrm{NO}_{2}$ requires $\mathrm{C}, 72.07$; $\mathrm{H}, 8.21 ; \mathrm{N}, 6.00 \%$.); $v_{\max }$ (neat) $3027,2949,2802,2760,1732,1494,1450,1435,1367,1320$, $1286,1268,1196,1167,1145,1047,1014,983,906,738$, and $699 \mathrm{~cm}^{-1} . \delta_{\mathrm{H}} 7.21-7.32(5 \mathrm{H}, \mathrm{m})$, $3.67(3 \mathrm{H}, \mathrm{s}), 3.48(2 \mathrm{H}, \mathrm{s}), 2.85(2 \mathrm{H}$, apparent d, J $11.9 \mathrm{~Hz}), 2.29(1 \mathrm{H}, \mathrm{tt}, J$ 4.0, $11.0 \mathrm{~Hz}), 2.02$ $(2 \mathrm{H}, \mathrm{dt}, J 2.3,11.6 \mathrm{~Hz}), 1.89-1.84(2 \mathrm{H}, \mathrm{m}), 1.82-1.71(2 \mathrm{H}, \mathrm{m}) ; \delta_{\mathrm{C}} 175.7,138.3,129.1(2 \mathrm{C})$, 128.1 (2C), 126.9, 63.2, 52.8 (2C), 51.5, 41.0, 28.2 (2C).

N-Benzyl-4-(2-hydroxy-2-propyl)piperidine (9). To a stirring solution of amine 8 (10 g, 42 $\mathrm{mmol})$ in THF $(50 \mathrm{~mL})$ at $0{ }^{\circ} \mathrm{C}$ was added dropwise a $3 \mathrm{M}$ solution of methyl magnesium bromide $(30 \mathrm{~mL}, 90 \mathrm{mmol})$. The mixture was then stirred at room temperature for $6 \mathrm{~h}$. After addition of a saturated solution of ammonium chloride $(20 \mathrm{~mL})$, the aqueous layer was extracted with $\mathrm{CH}_{2} \mathrm{Cl}_{2}(4 \times 30 \mathrm{~mL})$. The combined organic layers was dried $\left(\mathrm{Na}_{2} \mathrm{SO}_{4}\right)$, concentrated and the residual liquid was purified by chromatography over silica using 1:1 ether/methanol mixture as eluant to give the aminoalcohol 9 as a white solid $\left(7.3 \mathrm{~g}, 75 \%\right.$ ). Mp 75-76 ${ }^{\circ} \mathrm{C}$ (ether-pentane); (Found: C, 77.0; H, 10.1; N, 5.9. $\mathrm{C}_{15} \mathrm{H}_{23} \mathrm{NO}$ requires $\mathrm{C}, 77.21 ; \mathrm{H}, 9.93 ; \mathrm{N}, 6.00 \%$.); $v_{\max }(\mathrm{KBr})$ 3366, 2961, 2939, 2861, 2802, 2760, 1452, 1368, 1342, 1269, 1218, 1137, 1090, 997, 920, 759, 739 , and $700 \mathrm{~cm}^{-1} . \delta_{\mathrm{H}} 7.32-7.23(5 \mathrm{H}, \mathrm{m}), 3.49(2 \mathrm{H}, \mathrm{s}), 2.97(2 \mathrm{H}$, apparent d, $J 11.6 \mathrm{~Hz}), 1.92$ $(2 \mathrm{H}, \mathrm{dt}, J 2.3,11.7 \mathrm{~Hz}), 1.72-1.66(2 \mathrm{H}, \mathrm{m}), 1.39(2 \mathrm{H}, \mathrm{dq}, J 3.6,12.5 \mathrm{~Hz}), 1.32-1.24(2 \mathrm{H}, \mathrm{m})$, 
$1.17(6 \mathrm{H}, \mathrm{s}) ; \delta_{\mathrm{C}} 138.0,129.3(2 \mathrm{C}), 128.1(2 \mathrm{C}), 127.0,72.4,63.2,54.0(2 \mathrm{C}), 47.3,26.9(2 \mathrm{C})$, $26.7(2 \mathrm{C})$.

4-(2-Hydroxy-2-propyl)piperidine (10). Protected aminoalcohol 9 (10 g, $42 \mathrm{mmol}$ ) in ethanol $(50 \mathrm{~mL})$ containing $\mathrm{Pd} / \mathrm{C}(1 \mathrm{~g})$ was hydrogenated at $20{ }^{\circ} \mathrm{C}$ under 50 psi pressure for $3 \mathrm{~h}$. The reaction mixture was filtered over celite and washed with ethanol $(2 \times 10 \mathrm{~mL})$. After removal of the solvent, the residue was crystallized from acetone to give pure aminoalcohol $\mathbf{1 0}$ as a white solid (4.3 g, 72\%); mp 136-137 ${ }^{\circ} \mathrm{C} ; v_{\max }(\mathrm{KBr}) 3387,2970,2856,1643,1632,1537,1470,1426$, 1380, 1307, 1276, 1254, 1172, 1117, 915 and $818 \mathrm{~cm}^{-1} . \delta_{\mathrm{H}} 3.23(2 \mathrm{H}$, apparent d, $J 12.2 \mathrm{~Hz}), 2.92$ $(2 \mathrm{H}, \mathrm{br} \mathrm{s}), 2.63(2 \mathrm{H}, \mathrm{t}, J 11.7 \mathrm{~Hz}), 1.79(2 \mathrm{H}$, apparent d, $J 12.6 \mathrm{~Hz}), 1.46-1.28(3 \mathrm{H}, \mathrm{m}), 1.18$ $(6 \mathrm{H}, \mathrm{s}) ; \delta_{\mathrm{C}} 72.4,47.6,46.8(2 \mathrm{C}), 27.7(2 \mathrm{C}), 26.7(2 \mathrm{C})$.

4-(2-Hydroxy-2-propyl)- $N$-hydroxypiperidine (11). To a stirring solution of aminoalcohol 11 $(10 \mathrm{~g}, 70 \mathrm{mmol})$ in water $(100 \mathrm{~mL})$ in the presence of sodium tungstate $(0.8 \mathrm{~g})$ at $0^{\circ} \mathrm{C}$ under $\mathrm{N}_{2}$ was added dropwise a $30 \% \mathrm{H}_{2} \mathrm{O}_{2}$ solution $(18.5 \mathrm{~g}, 163 \mathrm{mmol})$ in $15 \mathrm{~min}$. The mixture was then stirred at $20^{\circ} \mathrm{C}$ for $2 \mathrm{~h}$. Solid sodium borohydride $(2 \mathrm{~g}, 54 \mathrm{mmol})$ was added in portions to the above mixture and stirring continued for $1 \mathrm{~h}$. The mixture was extracted with $\mathrm{CH}_{2} \mathrm{Cl}_{2}(4 \times 50 \mathrm{~mL})$. The combined organic layers was dried $\left(\mathrm{Na}_{2} \mathrm{SO}_{4}\right)$, concentrated and the residual liquid was purified by chromatography over silica using 70:30 ether/methanol mixture as eluant to give hydroxylamine 11 as a colorless liquid ( $8 \mathrm{~g}, 71 \%$ ). (Found: $\mathrm{C}, 60.2 ; \mathrm{H}, 10.6 ; \mathrm{N}, 8.7 . \mathrm{C}_{8} \mathrm{H}_{17} \mathrm{NO}_{2}$ requires $\mathrm{C}, 60.35 ; \mathrm{H}, 10.76 ; \mathrm{N}, 8.80 \%$.); $v_{\max }$ (neat) 3349, 2966, 2861, 2830, 1659, 1449, 1377, $1301,1254,1162,1131,1099,1049,921,794,733 \mathrm{~cm}^{-1} . \delta_{\mathrm{H}} 3.37-3.28(2 \mathrm{H}, \mathrm{m}), 2.47(2 \mathrm{H}, \mathrm{t}, J$ $10.5 \mathrm{~Hz}), 1.85-1.75(2 \mathrm{H}, \mathrm{m}), 1.50-1.37(4 \mathrm{H}, \mathrm{m}), 1.35-1.27(1 \mathrm{H}, \mathrm{m}), 1.17(6 \mathrm{H}, \mathrm{s}) ; \delta_{\mathrm{C}} 72.03$, $58.66(2 \mathrm{C}), 45.93,27.13(2 \mathrm{C}), 26.53(2 \mathrm{C})$.

4-(2-Hydroxy-2-propyl)-3,4,5,6-tetrahydropyridine 1-oxide (12). To a solution of the hydroxylamine ( $4.5 \mathrm{~g}, 28.2 \mathrm{mmol})$ in EtOH $(50 \mathrm{~mL})$ was added yellow $\mathrm{HgO}(12.0 \mathrm{~g}, 56.4 \mathrm{mmol})$ and the mixture was stirred at $20^{\circ} \mathrm{C}$ for $6 \mathrm{~h}$ or until the oxidation was complete (as indicated by TLC experiment in ether). The mixture was then filtered through a bed of celite and $\mathrm{MgSO}_{4}$. The bed was washed with liberal excess of ethanol. The formation of nitrone 12 was assumed quantitative for the percent yield calculation in the subsequent cycloaddition reactions. However, the nitrone contained minor quantities of impurities and as such its elemental analysis was not carried out. $v_{\max }$ (neat) $3360,2972,2938,1633,1446,1369,1299,1245,1162,1047,950,924$, 790,732 and $478 \mathrm{~cm}^{-1} . \delta_{\mathrm{H}} 7.18-7.15(1 \mathrm{H}, \mathrm{m}), 3.90-3.81(2 \mathrm{H}, \mathrm{m}), 2.55-2.48(1 \mathrm{H}, \mathrm{m}), 2.43-2.28$ $(2 \mathrm{H}, \mathrm{m}), 2.13-2.10(1 \mathrm{H}, \mathrm{m}), 1.70-1.83(2 \mathrm{H}, \mathrm{m}), 1.25(3 \mathrm{H}, \mathrm{s}), 1.24(3 \mathrm{H}, \mathrm{s}) ; \delta_{\mathrm{C}} 137.0,70.8,58.2$, 40.1, $27.3(\mathrm{Me}), 27.1,26.9(\mathrm{Me}), 23.9$. Assignment of the ${ }^{13} \mathrm{C}$ chemical shifts was based on DEPT experiment results.

2-Phenyl-5-(2-hydroxy-2-propyl)hexahydro-2H-isoxazolo[2,3-a]pyridine (14a). A solution of nitrone $12(10 \mathrm{mmol})$ in EtOH $(40 \mathrm{~mL})$ containing styrene 13a $(5 \mathrm{~mL})$ was heated at $90^{\circ} \mathrm{C}$ for $4 \mathrm{~h}$ under $\mathrm{N}_{2}$ in a closed vessel. After removal of the solvent and excess alkene the residual crude mixture was purified by chromatography over silica using 85:15 ether/methanol as eluant to give a single adduct 14a as a white solid $(2.0 \mathrm{~g}, 80 \%)$. ${ }^{1} \mathrm{H}$ NMR of the crude or the separated fraction failed to reveal the presence of any other minor isomers. $\mathrm{m} / \mathrm{z} 261\left[\mathrm{M}^{+}\right]$; $\mathrm{Mp} 87-89^{\circ} \mathrm{C}$ (ether- 
pentane); (Found: $\mathrm{C}, 73.3 ; \mathrm{H}, 8.7 ; \mathrm{N}, 5.3 . \mathrm{C}_{16} \mathrm{H}_{23} \mathrm{NO}_{2}$ requires $\mathrm{C}, 73.53 ; \mathrm{H}, 8.87 ; \mathrm{N}, 5.36 \%$.); $v_{\max }$ (neat) 3358, 2968, 2927, 2865, 1494, 1452, 1380, 1367, 1293, 1264, 1206, 1170, 1152, $1119,1093,952,921,758,731$, and $700 \mathrm{~cm}^{-1} ; \delta_{\mathrm{H}} 7.40-7.25(5 \mathrm{H}, \mathrm{m}), 5.40(1 \mathrm{H}, \mathrm{dd}, J 3.8,9.9 \mathrm{~Hz})$, 3.92-3.85 (1H, m), $3.25(1 \mathrm{H}, \mathrm{td}, J 3.4,10.4 \mathrm{~Hz}), 2.83(1 \mathrm{H}$, ddd, J 2.5, 10.4, $12.8 \mathrm{~Hz}), 2.75(1 \mathrm{H}$, $\mathrm{dt}, J 10.0,12.0 \mathrm{~Hz}), 2.05-1.70(5 \mathrm{H}, \mathrm{m}), 1.62-1.54(1 \mathrm{H}, \mathrm{tt}, J 3.0,12.0 \mathrm{~Hz}), 1.52-1.42(1 \mathrm{H}, \mathrm{dq}, J$ $3.4,12.8 \mathrm{~Hz}), 1.21(3 \mathrm{H}, \mathrm{s}), 1.20(3 \mathrm{H}, \mathrm{s}) ; \delta_{\mathrm{C}} 142.3,128.4(2 \mathrm{C}), 127.6,126.4(2 \mathrm{C}), 78.8(\underline{\mathrm{C}}-\mathrm{Ph})$, $72.1\left(\underline{\mathrm{CMe}}_{2}\right), 60.2,49.9,40.8(\underline{\mathrm{CCMe}})$, 38.8, 27.1 (Me), $27.0(\mathrm{Me}), 26.2,25.8$. Assignment of the ${ }^{13} \mathrm{C}$ chemical shifts was based on DEPT experiment results.

2-Butyl-5-(2-hydroxy-2-propyl)hexahydro-2H-isoxazolo[2,3-a]pyridine (14b). A solution of nitrone $12(10 \mathrm{mmol})$ in EtOH $(40 \mathrm{~mL})$ containing 1-hexene $13 \mathbf{b}(10 \mathrm{~mL})$ was heated at $90^{\circ} \mathrm{C}$ for $20 \mathrm{~h}$ under $\mathrm{N}_{2}$ in a closed vessel. After removal of the solvent and excess alkene the residual crude mixture was purified by chromatography over silica using 95:5 Dichloromethane/methanol as eluant to give only one adduct $\mathbf{1 4 b}$ as a colorless liquid $(1.85 \mathrm{~g}, 75 \%) . \mathrm{m} / \mathrm{z} 241\left[\mathrm{M}^{+}\right]$; mp 87$89^{\circ} \mathrm{C}$ (ether-pentane); (Found: C, 69.4; H, 11.1; N, 5.7. $\mathrm{C}_{14} \mathrm{H}_{27} \mathrm{NO}_{2}$ requires $\mathrm{C}, 69.67$; H, 11.27; $\mathrm{N}, 5.80 \%$.); $v_{\max }$ (neat) 3397, 2958, 2929, 2872, 1666, 1454, 1379, 1369, 1291, 1265, 1210, $1140,1098,954,926$, and $761 \mathrm{~cm}^{-1} ; \delta_{\mathrm{H}} 4.42-4.36(1 \mathrm{H}, \mathrm{m}), 3.64-3.58(1 \mathrm{H}, \mathrm{m}), 3.11(1 \mathrm{H}, \mathrm{td}, J 3.4$, $10.4 \mathrm{~Hz}), 2.68$ (1H, ddd, J 2.5, 10.2, $12.8 \mathrm{~Hz}), 2.36(1 \mathrm{H}, \mathrm{dt}, J 9.4,11.9 \mathrm{~Hz}), 1.97-1.20$ ( 13H, m), $1.19(3 \mathrm{H}, \mathrm{s}), 1.18(3 \mathrm{H}, \mathrm{s}), 0.90(3 \mathrm{H}, \mathrm{t}, J 7 \mathrm{~Hz}) ; \delta_{\mathrm{C}} 77.2,72.1,59.7,49.6,40.7,35.35,35.26$, $28.1,27.0$ (2C), 26.3, 25.7, 22.7, 14.0.

Isomers of methyl 2-methyl-5-(2-hydroxy-2-propyl)hexahydro-2H-isoxazolo[2,3-a]pyridine-2carboxylate (16 and 17). A solution of nitrone $12(10 \mathrm{mmol})$ in EtOH (40 mL) containing methyl methacrylate (15) $(6 \mathrm{~mL})$ was heated at $50^{\circ} \mathrm{C}$ for $3 \mathrm{~h}$ under $\mathrm{N}_{2}$ in a closed vessel. After removal of the solvent and excess alkene the residual crude mixture was separated by chromatography over silica using 95: $5 \mathrm{DCM} /$ methanol as eluant to give a nonseparable mixture of adducts 16 and 17 in a respective ratio of 95:5 as a colorless liquid $(2.1 \mathrm{~g}, 83 \%)$. The presence of the minor adduct was revealed by the presence of a $\mathrm{CO}_{2} \mathrm{Me}$ singlet at $3.75 \mathrm{ppm}$. Mp $128-129{ }^{\circ} \mathrm{C}$ (etherpentane); (Found: $\mathrm{C}, 60.5 ; \mathrm{H}, 9.1 ; \mathrm{N}, 5.3 . \mathrm{C}_{13} \mathrm{H}_{23} \mathrm{NO}_{4}$ requires $\mathrm{C}, 60.68 ; \mathrm{H}, 9.01 ; \mathrm{N}$, $5.44 \%$.); $v_{\max }$ (neat) 3404, 2968, 2930, 2872, 1731, 1652, 1454, 1371, 1293, 1251, 1217, 1191, $1139,1114,1084,987,946,920,874,738$ and $667 \mathrm{~cm}^{-1} ; \delta_{\mathrm{H}} 3.77(3 \mathrm{H}, \mathrm{s}), 3.79-3.74(1 \mathrm{H}, \mathrm{m}), 3.18$ $(1 \mathrm{H}, \mathrm{td}, J 3.4,10.4 \mathrm{~Hz}), 2.90(1 \mathrm{H}, \mathrm{t}, J 12.5 \mathrm{~Hz}), 2.65$ (1H, ddd, $J$ 2.5, 10.7, 13.0), 2.00-1.93 (2H, $\mathrm{m}), 1.91-1.33(1 \mathrm{H}, \mathrm{m}), 1.79-1.71(2 \mathrm{H}, \mathrm{m}), 1.54(1 \mathrm{H}, \mathrm{tt}, J 3.0,12.8 \mathrm{~Hz}), 1.50(3 \mathrm{H}, \mathrm{s}), 1.43-1.33$ $(1 \mathrm{H}, \mathrm{dq}, \mathrm{J} 3.4,12.8 \mathrm{~Hz}), 1.19(3 \mathrm{H}, \mathrm{s}), 1.18(3 \mathrm{H}, \mathrm{s}) ; \delta_{\mathrm{C}} 175.6,84.2,72.0,60.3(\underline{\mathrm{CHN}}), 52.6$ $\left(\mathrm{CO}_{2} \underline{\mathrm{Me}}\right), 50.8,40.8(\underline{\mathrm{CHCMe}})$, 39.6, 27.0 (2C, $\left.\underline{\mathrm{CMe}} 2\right), 25.86$ (2C), 25.75 (C-Me). Assignment of the ${ }^{13} \mathrm{C}$ chemical shifts was based on DEPT experiment results.

2-Phenyl-5-(2-acetoxy-2-propyl)hexahydro-2H-isoxazolo[2,3-a]pyridine (18). Cycloadduct 14a $(1.10 \mathrm{~g}, 4.3 \mathrm{mmol})$ in toluene $(20 \mathrm{~mL})$ was treated with acetic anhydride $(3 \mathrm{~mL})$ and DMAP [4( $N, N$-dimethylamino)pyridine] $(0.12 \mathrm{~g}, 1 \mathrm{mmol})$ at $70{ }^{\circ} \mathrm{C}$ for overnight. After removal of the solvent and excess acetic anhydride, the residual liquid was purified by chromatography over silica gel using 1:1 ether/hexane as eluant to give acetate 18 as a white solid (1.24 g, 95\%). Mp 58-60 ${ }^{\circ} \mathrm{C}$ (ether-pentane); (Found: $\mathrm{C}, 71.0 ; \mathrm{H}, 8.1 ; \mathrm{N}, 4.7 . \mathrm{C}_{18} \mathrm{H}_{25} \mathrm{NO}_{3}$ requires $\mathrm{C}, 71.26 ; \mathrm{H}, 8.31$; 
$\mathrm{N}, 4.62 \%$.); $v_{\max }(\mathrm{KBr}) 2977,2951,2930,2857,1728,1494,1453,1368,1257,1150,1133$, $1018,949,758$, and $701 \mathrm{~cm}^{-1} ; \delta_{\mathrm{H}} 7.37-7.25(5 \mathrm{H}, \mathrm{m}), 5.40(1 \mathrm{H}, \mathrm{dd}, J 3.8,9.9 \mathrm{~Hz}), 3.93-3.80(1 \mathrm{H}$, m), $3.27(1 \mathrm{H}, \mathrm{td}, J 3.4,10.3 \mathrm{~Hz}), 2.84(1 \mathrm{H}, \mathrm{ddd}, J 2.7,10.3,12.8 \mathrm{~Hz}), 2.76(1 \mathrm{H}, \mathrm{dt}, J 10.1,12.0$ $\mathrm{Hz}), 2.23(1 \mathrm{H}, \mathrm{tt}, J 3.35,12.3 \mathrm{~Hz}), 2.04(1 \mathrm{H}$, ddd, J 3.4, 7.6, $12.3 \mathrm{~Hz}), 1.98(3 \mathrm{H}, \mathrm{s}), 1.98-1.91$ $(1 \mathrm{H}, \mathrm{m}), 1.88-1.91(1 \mathrm{H}, \mathrm{m}), 1.77-1.71(1 \mathrm{H}, \mathrm{m}), 1.52(1 \mathrm{H}, \mathrm{dq}, J 3.1,12.8 \mathrm{~Hz}), 1.45(3 \mathrm{H}, \mathrm{s}), 1.43$ $(3 \mathrm{H}, \mathrm{s}) ; \delta_{\mathrm{C}} 170.5,142.2,128.5(2 \mathrm{C}), 127.6,126.4(2 \mathrm{C}), 84.0(\underline{\mathrm{CPh}}), 78.9\left(\mathrm{CMe}_{2} \underline{\mathrm{CO}}\right), 60.0,49.8$,

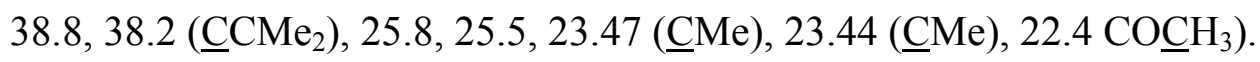

2-Butyl-5-(2-acetoxy-2-propyl)hexahydro-2H-isoxazolo[2,3-a]pyridine (19). Cycloadduct 14b $(1.30 \mathrm{~g}, 5.4 \mathrm{mmol})$ in toluene $(10 \mathrm{~mL})$ was treated with acetic anhydride $(3 \mathrm{~mL})$ and DMAP [4(N,N-dimethylamino) pyridine] ( $0.12 \mathrm{~g}, 1 \mathrm{mmol})$ at $70{ }^{\circ} \mathrm{C}$ for overnight. After removal of the solvent and excess acetic anhydride the residual liquid was purified by chromatography over silica gel using 80:20 ether-Hexanes as eluant to give the acetate $\mathbf{1 9}$ as a colourless liquid (1.30 g, 85\%). m/z $283\left[\mathrm{M}^{+}\right.$]; (Found: C, 67.6; H, 10.2; N, 4.8. $\mathrm{C}_{16} \mathrm{H}_{29} \mathrm{NO}_{3}$ requires C, 67.81; H, 10.31; $\mathrm{N}, 4.94 \%$.); $v_{\max }$ (neat) 2955, 2930, 2858, 1729, 1454, 1431, 1368, 1256, 1222, 1153, 1134, 1018,946 , and $759 \mathrm{~cm}^{-1} ; \delta_{\mathrm{H}} 4.43-4.36(1 \mathrm{H}, \mathrm{m}), 3.67-3.58(1 \mathrm{H}, \mathrm{m}), 3.11(1 \mathrm{H}, \mathrm{td}, J 3.4,10.40 \mathrm{~Hz})$, $2.68(1 \mathrm{H}, \mathrm{ddd}, J 2.7,10.4,12.9 \mathrm{~Hz}), 2.36(1 \mathrm{H}, \mathrm{dt}, J$ 9.4, $11.9 \mathrm{~Hz}), 2.16(1 \mathrm{H}, \mathrm{tt}, J$ 4.0, 11.9 $\mathrm{Hz}), 1.97(3 \mathrm{H}, \mathrm{s}), 1.90-1.76(2 \mathrm{H}, \mathrm{m}), 1.73-1.55(4 \mathrm{H}, \mathrm{m}), 1.53-1.25(5 \mathrm{H}, \mathrm{m}), 1.43(3 \mathrm{H}, \mathrm{s}), 1.41$ $(3 \mathrm{H}, \mathrm{s}), 0.90(3 \mathrm{H}, \mathrm{t}, J 7.0 \mathrm{~Hz}) ; \delta_{\mathrm{C}} 170.5,84.1,77.3,59.7,49.6,38.2,35.34,35.29,28.2,26.0$, $25.5,23.48,23.42,22.7,22.4,14.0$.

Methyl 2-methyl-5-(2-acetoxy-2-propyl)hexahydro-2H-isoxazolo[2,3-a]pyridine-2carboxylate (20). Cycloadduct $16(1.90 \mathrm{~g}, 7.4 \mathrm{mmol})$ in toluene $(10 \mathrm{~mL})$ was treated with acetic anhydride $(3 \mathrm{~mL})$ and DMAP $(0.12 \mathrm{~g}, 1 \mathrm{mmol})$ at $70{ }^{\circ} \mathrm{C}$ for overnight. After removal of the solvent and excess acetic anhydride the residual liquid was purified by chromatography over silica gel using 80:20 ether-hexane as a eluant to give acetate 20 as a colourless liquid (1.99 g, 90\%). (Found: $\mathrm{C}, 60.0 ; \mathrm{H}, 8.3 ; \mathrm{N}, 4.6 . \mathrm{C}_{15} \mathrm{H}_{25} \mathrm{NO}_{5}$ requires $\mathrm{C}, 60.18 ; \mathrm{H}, 8.42 ; \mathrm{N}, 4.68 \%$.); $v_{\max }$ (neat) 2959, 2951, 1730, 1454, 1370, 1255, 1192, 1137, 1116, 1086, 1019, 988, 947, 873, 757, and $608 \mathrm{~cm}^{-1} . \delta_{\mathrm{H}} 3.78(3 \mathrm{H}, \mathrm{s}), 3.80-3.75(1 \mathrm{H}, \mathrm{m}), 3.18(1 \mathrm{H}, \mathrm{td}, J 3.4,10.4 \mathrm{~Hz}), 2.87(1 \mathrm{H}, \mathrm{t}, J 12.5$ $\mathrm{Hz}), 2.66(1 \mathrm{H}, \mathrm{ddd}, J 2.5,10.7,13.0), 2.11-2.02(1 \mathrm{H}, \mathrm{m}), 1.96(3 \mathrm{H}, \mathrm{s}), 1.70-1.63(1 \mathrm{H}, \mathrm{m}), 1.99-$ $1.82(3 \mathrm{H}, \mathrm{m}), 1.50(3 \mathrm{H}, \mathrm{s}), 1.43(3 \mathrm{H}, \mathrm{s}), 1.41(3 \mathrm{H}, \mathrm{s}), 1.45-1.36(1 \mathrm{H}, \mathrm{m}) ; \delta_{\mathrm{C}} 175.5,170.4,84.3$, 83.8, 60.1 ( $\underline{\mathrm{CHN}}), 52.7(\mathrm{OMe}), 50.6,39.5,38.7(\underline{\mathrm{CHCMe}})$, $25.8(\mathrm{Me}), 25.6,25.4,23.4(\mathrm{Me})$, $23.3(\mathrm{Me}), 22.4(\mathrm{Me})$. Assignment of the ${ }^{13} \mathrm{C}$ chemical shifts was based on DEPT experiment results.

4-(2-Acetoxy-2-propyl)-6-(2-hydroxy-2-phenyl-1-ethyl)-3,4,5,6-tetrahydropyridine 1-oxide (21). To a stirred solution of cycloadduct $18(3.0 \mathrm{mmol})$ in dichloromethane $(30 \mathrm{~mL})$ at $20^{\circ} \mathrm{C}$ was added MCPBA $(3.0 \mathrm{mmol})$ in one portion. After $30 \mathrm{~min}$ at $20{ }^{\circ} \mathrm{C}$ the organic layer was washed with $5 \% \mathrm{NaHCO}_{3}$ solution $(3 \times 10 \mathrm{~mL})$. The combined aqueous layers was re-extracted with $\mathrm{CH}_{2} \mathrm{Cl}_{2}(3 \times 25 \mathrm{~mL})$. The combined organic layers was dried $\left(\mathrm{Na}_{2} \mathrm{SO}_{4}\right)$, concentrated to give only aldonitrone 21 as a pale yellow liquid in almost quantitative yield. The crude nitrone was not purified further and its elemental analysis was not carried out. $v_{\max }$ (neat) 3250, 2981, 2929, $1729,1621,1493,1454,1431,1370,1257,1224,1167,1138,1098,1019,914,760$, 733, and 
$703 \mathrm{~cm}^{-1} ; \delta_{\mathrm{H}} 7.43-7.21(5 \mathrm{H}, \mathrm{m}), 7.21-7.17(1 \mathrm{H}, \mathrm{m}), 6.17(1 \mathrm{H}, \mathrm{br} \mathrm{s}), 5.08-5.03(1 \mathrm{H}, \mathrm{dd}, J 2.7,6.4$ $\mathrm{Hz}), 4.15-4.08(1 \mathrm{H}, \mathrm{m}), 2.55-2.45(1 \mathrm{H}, \mathrm{m}), 2.42-2.30(3 \mathrm{H}, \mathrm{m}), 2.03-1.98(1 \mathrm{H}, \mathrm{m}), 1.97(3 \mathrm{H}$, $\mathrm{s}), 1.88-1.82(1 \mathrm{H}, \mathrm{m}), 1.72-1.67(1 \mathrm{H}, \mathrm{m}), 1.46(3 \mathrm{H}, \mathrm{s}), 1.42(3 \mathrm{H}, \mathrm{s}) ; \delta_{\mathrm{C}} 170.1,143.8,137.5$, 128.3 (2C), 127.0, 125.7 (2C), 82.2, 70,2, 63.1, 44.2, 34.4, 29.9, 27.0, 23.2, 23.1, 22.2.

4-(2-Acetoxy-2-propyl)-6-(2-hydroxy-1-hexyl)-3,4,5,6-tetrahydropyridine 1-oxide (22). Using procedure as described in the preparation of 21, cycloadduct 19 (3.0 mmol) was treated with MCPBA to generate the aldonitrone 22 as a pale yellow liquid in almost quantitative yield. The crude nitrone was not purified further and its elemental analysis was not carried out. $v_{\max }$ (neat) $3357,2932,2871,1729,1631,1454,1370,1256,1224,1170,1139,1019,921,788$, and $732 \mathrm{~cm}^{-1} ; \delta_{\mathrm{H}} 7.16(1 \mathrm{H}, \mathrm{t}, J 3.8 \mathrm{~Hz}), 5.02(1 \mathrm{H}, \mathrm{br} \mathrm{s}), 4.33-4.22(1 \mathrm{H}, \mathrm{m}), 3.92-3.78(1 \mathrm{H}, \mathrm{m}), 2.55-$ $2.30(4 \mathrm{H}, \mathrm{m}), 2.10-1.90(2 \mathrm{H}, \mathrm{m}), 2.00(3 \mathrm{H}, \mathrm{s}), 1.88-1.80(1 \mathrm{H}, \mathrm{m}), 1.70-1.22(6 \mathrm{H}, \mathrm{m}), 1.50(3 \mathrm{H}$, s), $1.47(3 \mathrm{H}, \mathrm{s}) .0.91(3 \mathrm{H}, \mathrm{t}, J 7.0 \mathrm{~Hz}), \delta_{\mathrm{C}} 170.2,136.7,82.4,68.2,63.7,42.1,36.5,34.2,29.2$, 28.2, 26.9, 23.3, 23.2, 22.7, 22.3, 14.1.

4-(2-Acetoxy-2-propyl)-6-(2-hydroxy-2-carbomethoxy-1-propyl)-3,4,5,6-tetrahydropyridine 1-oxide (23). Using procedure as described in the preparation of 21, cycloadduct $20(3.0 \mathrm{mmol})$ was treated with MCPBA to generate aldonitrone 23 as a pale yellow liquid in almost quantitative yield. The crude nitrone was not purified further and its elemental analysis was not carried out. $v_{\max }$ (neat) 3438, $29811728,1713,1644,1631,1554,1537,1516,1452,1371,1256$, $1137,1020,918,732,645$ and $611 \mathrm{~cm}^{-1} . \delta_{\mathrm{H}} 7.09-7.06(1 \mathrm{H}, \mathrm{m}), 6.46(1 \mathrm{H}$, br s$), 4.24-4.18(1 \mathrm{H}$, m), $3.75(3 \mathrm{H}, \mathrm{s}), 2.64(1 \mathrm{H}, \mathrm{dd}, \mathrm{J} 10.2,14.3 \mathrm{~Hz}), 2.58-2.25(3 \mathrm{H}, \mathrm{m}), 1.99(3 \mathrm{H}, \mathrm{s}), 2.02-1.77(2 \mathrm{H}$, $\mathrm{m}), 1.51(3 \mathrm{H}, \mathrm{s}), 1.50(3 \mathrm{H}, \mathrm{s}), 1.48(3 \mathrm{H}, \mathrm{s}), 1.54-1.37(1 \mathrm{H}, \mathrm{m}) ; \delta_{\mathrm{C}} 176.2,170.0,137.5,82.1$, $73.2,62.4,52.4,43.6,34.7,28.9,26.8,26.7,23.2$ (2C), 22.2.

Reaction of nitrone 21 with methymethacrylate (15). Nitrone 21 [prepared by MCPBA oxidation of adduct $18(1.0 \mathrm{mmol})]$ in $\mathrm{CH}_{2} \mathrm{Cl}_{2}(10 \mathrm{~mL})$ was treated with methyl methacrylate (15) $(1.0 \mathrm{~mL})$ and the mixture was stirred at $45^{\circ} \mathrm{C}$ for overnight. After removal of the solvent and excess alkene, the residual liquid was purified by chromatography over silica gel using 9:1 ether/hexane as eluant to give a nonseparable mixture of three adducts (as indicated by the presence of three $\mathrm{CO}_{2} \mathrm{Me}$ singlets at $\delta 3.77,3.80$ and $3.84 \mathrm{ppm}$ in a respective ratio of $89: 8: \sim 1$ as a colourless liquid (380 mg, 91\%). The major adduct was assigned the stereochemistry of 25. (Found: C, 65.6; H, 7.7; N, 3.2. $\mathrm{C}_{23} \mathrm{H}_{33} \mathrm{NO}_{6}$ requires $\mathrm{C}, 65.85 ; \mathrm{H}, 7.93 ; \mathrm{N}, 3.34 \%$.); $v_{\max }$ (neat) 3475, 2982, 2951, 2872, 1728, 1653, 1448, 1368, 1254, 1215, 1125, 1057, 1020, 936, 754, 700, $609 \mathrm{~cm}^{-1} ; \delta_{\mathrm{H}} 7.40-7.23(5 \mathrm{H}, \mathrm{m}), 5.00(1 \mathrm{H}, \mathrm{m}), 3.77(3 \mathrm{H}, \mathrm{s}), 3.77-3.70(2 \mathrm{H}, \mathrm{m}), 2.43-2.20(4 \mathrm{H}$, $\mathrm{m}), 1.95(3 \mathrm{H}, \mathrm{s}), 1.98-1.22(6 \mathrm{H}, \mathrm{m}), 1.56(3 \mathrm{H}, \mathrm{s}), 1.37(3 \mathrm{H}, \mathrm{s}), 1.35(3 \mathrm{H}, \mathrm{s}) ; \delta_{\mathrm{C}} 174.2,170.3$, 144.6, 128.3 (2C),126.9, 125.5 (2C), 84.1, 80.3, 72.6, 56.0, 54.8, 52.6, 46.2, 38.4 (2C), 27.5, 25.4 (2C), 23.14, 23.06, 22.4.

Reaction of nitrone 21 with styrene 13a. Nitrone 21 [prepared by MCPBA oxidation of adduct $18(2.0 \mathrm{mmol})]$ in $\mathrm{CH}_{2} \mathrm{Cl}_{2}(10 \mathrm{~mL})$ was treated with styrene $(2.0 \mathrm{~mL})$ and the mixture was stirred at $45^{\circ} \mathrm{C}$ for overnight. After removal of the solvent and excess alkene, the residual liquid was separated by chromatography over silica gel using 7:1 ether/hexane as eluant to give the minor isomer 26 as a colorless liquid $(90 \mathrm{mg}$ ). Continued elution gave a mixture of $\mathbf{2 6}$ and 27. Finally, 
the major adduct 27 was eluted as a colorless liquid. The total isolated yield was $82 \%$ and respective ratio of $\mathbf{2 6}$ and $\mathbf{2 7}$ was found to be 1:3.

Minor diastereomer 26. (Found: $\mathrm{C}$, 77.4; $\mathrm{H}, 7.7$; $\mathrm{N}, 3.2 . \mathrm{C}_{26} \mathrm{H}_{33} \mathrm{NO}_{4}$ requires $\mathrm{C}, 73.73$; $\mathrm{H}, 7.85$; $\mathrm{N}, 3.31 \%$.); $v_{\max }$ ( neat ) 3446, 3027, 2947, 2880, 1725, 1656, 1493, 1454, 1369, 1258, 1221, $1132,1055,1020,946,913,759,733$ and $701 \mathrm{~cm}^{-1} ; \delta_{\mathrm{H}} 7.40-7.20(10 \mathrm{H}, \mathrm{m}), 5.13-5.09(1 \mathrm{H}, \mathrm{m})$, 5.06-5.02 (1H, m), 3..72-3.60 (2H, m), 2.50- $2.28(5 \mathrm{H}, \mathrm{m}), 1.98(3 \mathrm{H}, \mathrm{s}), 1.75-1.22(5 \mathrm{H}, \mathrm{m}), 1.41$ $(3 \mathrm{H}, \mathrm{s}), 1.38(3 \mathrm{H}, \mathrm{s}) ; \delta_{\mathrm{C}} 170.4,144.6,141.7,128.5(2 \mathrm{C}), 128.2(2 \mathrm{C}), 127.4,126.8,125.6(4 \mathrm{C})$, $84.2,76.5,72.3,56.3,54.4,44.6,39.6,38.4,27.3,25.2,23.1(2 \mathrm{C}), 22.4$.

Major distereomer 27. (Found: $\mathrm{C}$, 73.4; $\mathrm{H}, 7.6 ; \mathrm{N}, 3.2 . \mathrm{C}_{26} \mathrm{H}_{33} \mathrm{NO}_{4}$ requires $\mathrm{C}, 73.73$; $\mathrm{H}, 7.85$; $\mathrm{N}, 3.31 \%$.); $v_{\max }$ (neat) 3429, 3064, 3026, 2945, 1726, 1451, 1367, 1253, 1136, 1018, 782, 753, and $698 \mathrm{~cm}^{-1} ; \delta_{\mathrm{H}} 7.40-7.20(10 \mathrm{H}, \mathrm{m}), 5.20-5.05(2 \mathrm{H}, \mathrm{m}), 4.60(1 \mathrm{H}, \mathrm{br} \mathrm{s}), 3.41-3.32(1 \mathrm{H}, \mathrm{m})$, 3.10-3.00 (1H, m), 2.50-1.40 $(9 \mathrm{H}, \mathrm{m}), 1.96(3 \mathrm{H}, \mathrm{s}), 1.52(6 \mathrm{H}, \mathrm{s}) ; \delta_{\mathrm{C}} 170.1,144.7,141.8,128.4$ (2C), 128.2 (2C), 127.8, 126.9, 126.4 (2C), 125.7 (2C), 84.3, 78.6, 71.5, 61.3, 59.2, 43.9, 43.6, 40.3, 29.7, 29.3, 24.8, 24.2, 22.6.

Conversion of 27 to 28 by treatment with zinc and acetic acid. To a vigorously stirred solution of adduct $27(0.3 \mathrm{mmol})$ in acetic acid $(2 \mathrm{~mL})$ and water $(2 \mathrm{~mL})$ at $60{ }^{\circ} \mathrm{C}$ was added $\mathrm{Zn}$ $(0.85 \mathrm{~g})$ in two portions (ca. $5 \mathrm{~min})$. The reaction mixture was stirred at $60^{\circ} \mathrm{C}$ for a total $30 \mathrm{~min}$. The reaction mixture was decanted and the residual solid was washed with water $(10 \mathrm{~mL})$ and $\mathrm{CH}_{2} \mathrm{Cl}_{2}(20 \mathrm{~mL})$. After basification $\left(\mathrm{K}_{2} \mathrm{CO}_{3}\right)$, the aqueous layer was extracted with $\mathrm{CH}_{2} \mathrm{Cl}_{2}$ $(3 \times 20 \mathrm{~mL})$. The organic layer was dried $\left(\mathrm{Na}_{2} \mathrm{SO}_{4}\right)$, concentrated to give the amine 28 in almost quantitative yield. Mp. $134-137^{\circ} \mathrm{C}$; (Found: C, 73.1; H, 8.0; N, 3.2. $\mathrm{C}_{26} \mathrm{H}_{35} \mathrm{NO}_{4}$ requires C, 73.38; H, 8.29; N, 3.29\%.); $v_{\max }(\mathrm{KBr}) 3410$, 3297, 3126, 3066, 2978, 2858, 2844, 1735, 1638, $1550,1425,1372,1330,1249,1216,1108,1059,1013,923,752,703$, and $649 \mathrm{~cm}^{-1} ; \delta_{\mathrm{H}} 7.45$ $(4 \mathrm{H}, \mathrm{d}, J 7.3 \mathrm{~Hz}), 7.32(4 \mathrm{H}, \mathrm{t}, J 7.3 \mathrm{~Hz}), 7.22(2 \mathrm{H}, \mathrm{t}, J 7.3 \mathrm{~Hz}), 6.25-4.252 \mathrm{H}, \mathrm{br}, \mathrm{OH}), 5.19(2 \mathrm{H}$, t, J 4.0 Hz), $3.28(2 \mathrm{H}, \mathrm{t}, J 10.7 \mathrm{~Hz}), 2.47(2 \mathrm{H}$, ddd, J 4.1, 10.1, $14.7 \mathrm{~Hz}), 1.98(3 \mathrm{H}, \mathrm{s}), 1.90-1.70$ $(7 \mathrm{H}, \mathrm{m}), 1.55-1.45(1 \mathrm{H}, \mathrm{m}), 1.34(6 \mathrm{H}, \mathrm{s}) ; \delta_{\mathrm{C}} 169.9,143.4(2 \mathrm{C}), 128.6(4 \mathrm{C}), 127.2(2 \mathrm{C}), 125.6$ (4C), 84.0, 69.8 (2C), 49.4 (2C), 41.0 (2C), 40.6, 29.1 (2C), 24.5 (2C), 21.8.

1-Oxa-5,6-dehydro-6-aza-bicyclo[3,2,1]heptane 6-oxide (29). To a solution of hydroxylamine $11(0.796 \mathrm{~g}, 5.0 \mathrm{mmol})$ in dry $\mathrm{CHCl}_{3}(50 \mathrm{~mL})$ was added yellow $\mathrm{HgO}(4.3 \mathrm{~g}, 20 \mathrm{mmol})$ and the mixture was stirred using a magnetic stir bar at $20^{\circ} \mathrm{C}$ for overnight or until the oxidation was complete (as indicated by TLC experiment in ether). The mixture was then filtered through a bed of celite and $\mathrm{MgSO}_{4}$. After removal of the solvent, the bicyclic nitrone 29 was obtained as a solid in almost quantitative yield. $\mathrm{Mp} 87-89^{\circ} \mathrm{C}$ (ether); (Found: $\mathrm{C}, 61.7 ; \mathrm{H}, 8.3 ; \mathrm{N}, 8.9 . \mathrm{C}_{8} \mathrm{H}_{13} \mathrm{NO}_{2}$ requires $\mathrm{C}, 61.91 ; \mathrm{H}, 8.44 ; \mathrm{N}, 9.03 \%$.); $v_{\max }(\mathrm{KBr}) 3296,2972,2937,1642,1605,1451,1369$, $1303,1195,1176,1142,1117,1088,1059,1032,963$ and $899 \mathrm{~cm}^{-1} ; \delta_{\mathrm{H}} 6.82-6.79(1 \mathrm{H}, \mathrm{m}), 5.18$ $(1 \mathrm{H}, \mathrm{d}, J 3.5 \mathrm{~Hz}), 2.66-2.48(3 \mathrm{H}, \mathrm{m}), 2.40-2.36(1 \mathrm{H}, \mathrm{m}), 2.21(1 \mathrm{H}, \mathrm{d}, J 12.3 \mathrm{~Hz}), 1.38(3 \mathrm{H}, \mathrm{s})$, $1.30(3 \mathrm{H}, \mathrm{s}) ; \delta_{\mathrm{C}} 130.2,98.0,85.3,38.2,34.5,28.9,28.6,24.6$. 


\section{Acknowledgements}

The facilities provided by the King Fahd University of Petroleum and Minerals, Dhahran, are gratefully acknowledged.

\section{References}

1. For reviews on 1,3-dipolar cycloaddition reactions of cyclic nitrones, see: (a) De March, P.; Figueredo, M.; Font, J. Heterocycles 1999, 50, 1213. (b) Merino, P. Science of Synthesis 2004, 27, 511. (c) Verboom, W.; Reinhoudt, D. N. Bull. Soc. Chim. Fr. 1990, 704.

2. (a) Ali, S. A.; Wazeer, M. I. M. J. Chem. Soc., Perkin Trans. I 1988, 597. (b) Ali, S. A.; Wazeer, M. I. M. J. Chem. Soc., Perkin Trans. 2 1986, 1789; (c) Ali, S. A.; Wazeer, M. I. M. Tetrahedron 1988, 44, 187. (d) Ali, S. A.; Khan, J. H.; Wazeer, M. I. M., Tetrahedron 1988, 44, 5911. (e) Ali, S. A.; Khan, J. H.; Wazeer, M. I. M.; Perzanowski, H. P Tetrahedron 1989, 45, 5979.

3. (a) For a review on asymmetric 1,3-dipolar cycloaddition reactions, see: Goethelf, K. V.; Jorgensen, K. A. Chem. Rev. 1998, 98, 863. (b) For a review on enantiopure cyclic nitrones for asymmetric synthesis, see: Revuelta, J.; Cicchi, S.; Goti, A.; Brandi, A. Synthesis 2007, 4, 485.

4. (a) Tufariello, J. J. 1,3-Dipolar Cycloaddition Chemistry; Padwa, A., Ed.; WileyInterscience: New York, N Y 1984, Vol. 2, Ch. 9, pp 83-168. (b) Confalone, P. N.; Huie, E. M. Org. React. 1988, 36, 1. (c) Iida, H.; Kibayashi, C. Yuki Gosei Kagaku Kyokaishi 1983, 41,652 .

5. (a) LeBel, N. A.; Spurlock, L. A. J. Org. Chem. 1964, 29, 1337. (b) Tufariello, J. J.; Mullen, J. B.; Tribulski, E. J.; Wong, S. C.; Ali, S. A. J. Am. Chem. Soc. 1979, 101, 2435. (c) LeBel, N. A.; Post, M. E.; Hwang, D. J. Org. Chem. 1979, 44, 1819.

6. Ali, S. A.; Wazeer, M. I. M. Tetrahedron 1993, 49, 4339.

7. (a) Carruthers, W.; Coggins, P.; Weston, J. B. J. Chem. Soc., Perkin Trans. 1 1990, 2323. (b) Ali, S. A.; Wazeer, M. I. M. Tetrahedron Lett. 1992, 33, 3219. (c) Perzanowski, H. P.; A1Jaroudi, S. S.; Wazeer, M. I. M.; Ali, S. A. Tetrahedron 1997, 53, 11869. (d) Ali, S. A. J. Chem. Res. (S) 1994, 32. (e) Ali, S. A. J. Chem. Res. (S) 1994, 54. (M) 301.

8. Eliel, E. L.; Allinger, N. L.; Angyal, S. J.; Morrison G. A., Conformational Analysis, $2^{\text {nd }}$ Edn, Interscience, N. Y., 1966, p.28.

9. Perzanowski, H. P.; Al-Jaroudi, S. S.; Wazeer, M. I. M.; Ali, S. A. Tetrahedron 1997, 53, 11869.

10. AlSbaiee, A.; Ali, S. A. Tetrahedron 2008, 64, 6635.

11. Moosa, B. A.; Ali, S. A. Tetrahedron 2009, 65, 8231.

12. Choudary, B. M.; Bharathi, B.; Reddy, C. V.; Kantam, M. L. Green Chemistry 2002, 4, 279. 
13. (a) Raban, M.; Cost, D. Tetrahedron 1984, 40, 3345. (b) Raban, M.; Jones, Jr. F. B.; Carlson, E. H.; Bannuci, E.; LeBel, N. A. J. Org. Chem. 1970, 35, 1496, and references cited therein. (c) Riddel, F. G. Tetrahedron 1981, 37, 849.

14. (a) Kurteva, V. B.; Lyapova M. J.; Pojarlieff, I. G. Arkivoc 2006, (ii), 91. (b) Ali, S. A.; Wazeer, M. I. M.; Fettouhi, M. B.; Iman, M. Z. N. Arkivoc 2008, (xvi), 255. (c) Ali, S. A.; AlSbaiee, A.; Wazeer, M. I. M. Arkivoc 2008, (xvii), 96.

15. (a) Ali, S. A.; Wazeer, M. I. M. Tetrahedron Lett. 1993, 34, 137. (b) Wazeer, M. I. M.; A1Muallem, H. A.; Ali, S. A. J. Phys. Org. Chem. 1993, 6, 326.

16. Wazeer M. I. M.; Ali, S. A. Magn. Reson. Chem. 1993, 31, 12.

17. Berge, J. M.; Broom, N. J. P.; Houge-Frydrych, C. S. V.; Jarvest, R. L.; Mensah, L.; McNair, D. J.; O’Hanlon, P. J.; Pope, A. J.; Rittenhouse, S. J Antibiot. 2000, 53, 1282. 